\title{
Self-Instruction Technical Guidelines to Improve High School Students's Self-Discipline
}

\author{
Rosalia Dewi Nawantara, Laelatul Arofah, Nora Yuniar Setyaputri \\ Department of Guidance and Counseling \\ Universitas Nusantara PGRI Kediri \\ Kediri, Indonesia \\ rosaliadewi@unpkediri.ac.id
}

\begin{abstract}
Low of self-discipline is flare phenomenon in schools. The self-instruction technique guide is one of the media that can be used to improve self-discipline by targeting individual self-talk. This study aims to determine the acceptance of the selfinstruction technical guidelines to improve high school students' self-discipline theoretically and practically as one type of guidance and counseling media. The research method used is Research and Development which adapts the development model of Borg and Gall. The results showed that the self-instruction technical guidelines to improve high school students' selfdiscipline could be accepted theoretically and practically as a type of guidance and counseling media, which means there are differences in the level of student self-discipline before and after technical guidance is given self-instruction.
\end{abstract}

Keywords—self-instruction technique; self-discipline

\section{INTRODUCTION}

Self-discipline is an attribute that is very important for the formation of student character. That is why the problem of selfdiscipline is often a concern at school. Many of the sanctions given by schools are related to disciplinary violations such as truant behavior during class hours, do not use complete school attributes, and are late when coming to school. Based on research conducted by Arofah [1], it was found that violations of academic self-discipline which are often found include some students often arrive late, damage the infrastructure at school, procrastinate in doing assignments and cheat when the test takes place. This is supported by a preliminary study conducted at Public Senior High School 1 Srengat through the observation method that there are several behaviors that are contrary to self-discipline, which are some students who are late for school, violating school rules such as not using full school attributes.

The behavior of self-discipline is a behavior that should be instilled early. This attitude helps students to control their behavior. Bryant [2] explains that self-discipline is not a character that a person has or does not have, not an action that forces himself against himself to act using his strength. Selfdiscipline is also a process of coordinating mental elements that come from consciously inside. It shows that self-discipline is an overall element of the individual that allows the individual to control, direct, and regulate his behavior.
The cause of the problem of self-discipline is dysfunctional thoughts. Dysfunctional thoughts are thoughts that can emit certain feelings / emotions, which are finally followed by behavior or actions that are in harmony with the thoughts and feelings that arise [3]. Dysfunctional thoughts related to selfdiscipline are to assume that violating behavior is something normal, consider violating the rules is something cool, and other assumptions that deviate. Dysfunctional thoughts are influenced by negative self-statements, which can be modified with positive self-statements or positive self-sentences using CBM (Cognitive Behavior Modification) with self-instruction techniques [4].

Self-discipline is an ability that can be learned, aware of every action that comes from within who can then be responsible for his actions. Because self-discipline is the ability or behavior that can be learned, efforts can be made to improve it. The self-instruction technique is included in CBM. According to Meichenbaum [5], to understand a cognitive event and the occurrence of a behavior, special attention needs to be paid to inner speech or self-talk. Meichenbaum also explained that the core of the self-instruction technique is developing self-control. Through counselee self-instruction techniques can control themselves in thinking and acting by having a positive self-verbalization.

The self-instruction technique contains steps that will be maximized if implemented using guidance and counseling media. The guidance and counseling media used to implement the self-instruction technique is a guide. The guide used in this study is a printed guide that is designed attractively and adapted to the stages of self-instruction techniques. It is expected that through these guidelines the guidance and counseling teacher can be helped in implementing selfinstruction techniques to improve self-discipline of high school students.

\section{METHOD}

The development model of the self-instruction technique guide uses the adaptation of the development model proposed by Gall et al [6]. As for the steps of the Borg and Gall research model in this study, the researcher did not use the steps above as a whole. This research and development uses seven stages namely 1) the stage of data collection; 2) the planning stage; 3) develop initial products; 4) trials of material and media 
experts; 5) media revision; 6) prospective product user tests; and 7) final stage revisions.

The procedure for developing this self-instruction technique guide was adapted from Gall's [6] research procedure. Researchers do not fully use the Borg and Gall development model. The development of self-instruction techniques is carried out up to the prospective product user test stage. The steps of the research procedure are attached in figure 1.

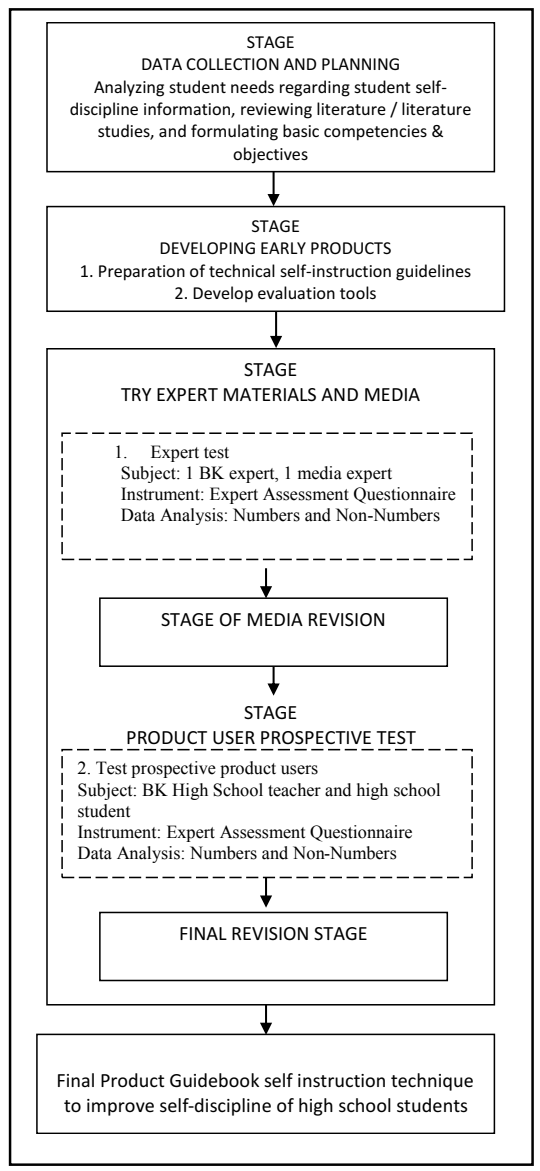

Fig. 1 Adaptation Model of Borg and Gall Development [6]

Product trial phase is carried out to obtain data in the form of assessments, suggestions, and responses from test subjects that can be used as a basis for improving the resulting product development. In the trial phase, sequential design of the trial, test subjects, types of data, data collection instruments, and data analysis techniques are presented.

The product trial design is intended to test the acceptability of the development product, which will be used to determine the usability, accuracy and viability of the product. The trial was carried out with product assessments conducted by material experts, media experts, and prospective product users namely guidance and counseling teachers and high school students.

Based on the design of the trial, there are two types of test subjects in this research development. the chosen trial subjects were guidance and counseling material experts and media experts, as well as potential product users. criteria for guidance and counseling material experts are: a) guidance and counseling lecturers, b) master graduate lecturers, c) guidance and counseling experts in the service sector. While the criteria for media experts are: a) lecturers, b) lecturers with graduate degrees, c) experts in the field of media.

The prospective test subjects for selected guidance and counseling teacher product users are two teachers in Public Senior High School 1 Srengat, who have taken at least S1 guidance and counseling education. Whereas the next prospective product user test is a high school student is a class XI student at Public Senior High School 1 Srengat who has been chosen based on observations and interviews with the guidance and counseling teacher. The population then uses a purposive sampling technique to get representative samples that show sample criteria. Sample criteria are having a low level of self-discipline that is known through a scale of selfdiscipline and found eight people as a sample.

Data obtained from product trials include assessments of several aspects depending on what tests will be carried out such as usability, accuracy, and feasibility. The data obtained are numerical (quantitative) and non-numerical (qualitative). Quantitative data were obtained using a rating scale given to experts and prospective users of the product (guidance and counseling teachers and students), while qualitative data were in the form of suggestions or criticisms in writing on the suggestion sheet, or verbally at the time of the interview.

Data collection instruments used were assessment questionnaires, and interviews. The assessment questionnaire used consisted of a material expert questionnaire, a media expert test questionnaire, and a guidance and counseling teacher questionnaire. In the questionnaire, there is a written statement that can be used to obtain information from guidance and counseling material experts, media experts, and prospective product users (guidance and counseling teachers) regarding the acceptability of guidelines developed by researchers. It also used the scale of student self-discipline to carry out prospective product user tests on students conducted in small group tests. The scale of self-discipline is used to measure the level of student self-discipline before and after treatment using a self-instruction technique guide.

Data analysis was carried out quantitatively and qualitatively. Quantitative data is obtained by finding the percentage of the score for the observations with the maximum score and the intervals of the expert assessment results to determine the range of each criterion. The formula used to find percentages is (score of observations) / (maximum score) $\mathrm{x} 100 \%$ [7]. While qualitative data in the form of comments, suggestions, criticisms, were analyzed with descriptive analysis.

\section{RESUlTS AND DISCUSSION}

In the results and discussion chapter, the results of the product development and discussion will be explained respectively based on Borg and Gall steps. The initial stage taken is the data collection and planning stage. At this stage a preliminary study or data collection was conducted at Public Senior High School 1 Srengat. In addition, at this stage a 
literature review and formulation of basic competencies and the purpose of guidance and counseling services are to be targeted.

The next stage is the stage of developing the initial product. At this stage, the resulting development product consists of a self-instruction technique manual which includes the production of a self-instruction technique guide for high school students and the stages of preparing a self-instruction technique for high school students. The stages of the preparation include determining the background and objectives of the preparation of the self-instruction technique guide and compiling the variable description that will be used as the contents of the guide. self-instruction techniques will be explained in table 1 .

TABLE I. CONTENT OF SELF INSTRUCTION TECHNICAL GUIDELINES

\begin{tabular}{|l|l|l|}
\hline \multirow{4}{*}{$\begin{array}{l}\text { Chapter } \\
\text { I }\end{array}$} & \multirow{2}{*}{$\begin{array}{l}\text { Preface } \\
\text { II }\end{array}$} & $\begin{array}{l}\text { a. Introduction to Guidance and } \\
\text { Counselling's Teacher }\end{array}$ \\
\cline { 3 - 3 } & \multirow{4}{*}{$\begin{array}{l}\text { belf-Instruction } \\
\text { General } \\
\text { Guidance }\end{array}$} & $\begin{array}{l}\text { Technique } \\
\text { a. Purpose }\end{array}$ \\
\cline { 3 - 3 } & b. User Target \\
\hline \multirow{5}{*}{$\begin{array}{l}\text { c. Implementation of the Self } \\
\text { Instruction Technique }\end{array}$}
\end{tabular}

During the initial product development phase evaluation tools were also developed. Evaluation tools used in this study are in the form of material expert rating, media expert, and prospective product users. After the evaluation tools are ready, the next step is to conduct material expert test and media expert test. Expert testing was carried out by material experts and media experts. While testing prospective product, users was conducted by two counseling teachers and high school students. Based on expert judgment, quantitative (number) and qualitative (not number) data were analyzed descriptively. Next, expert judgment data will be explained as follows.

The first assessment results are the results of the material expert test evaluator. Number data in this study were obtained from the results of the assessment of subject matter expert material through the guidance and counseling expert material test instrument. The instrument assesses several aspects of this guide such as aspects of accuracy, appropriateness, and clarity. From the expert material test instrument obtained data figures $79 \%$ which shows that the manual specifications of independent teaching techniques to improve self-discipline of middle school students are in the excellent category.

In addition to using the above numerical data, the results of the expert expert's assessment of the material in the form of non-numeric or qualitative suggestions / inputs are also considered by the researcher. The first suggestion is about the completeness of the guidelines using evaluation results and the evaluation process. In addition, input is also about indicators of self-discipline that must be considered to facilitate the formulation of specific goals and general goals.

The second assessment result is the test data of media experts. Numerical data in the media expert test was obtained from the results of the media expert test. The instrument assesses several aspects of this guide such as aspects of accuracy, appropriateness, clarity, and attractiveness. From the results of the instrument obtained $95 \%$ numerical data which shows that the manual specifications of independent learning techniques to improve self-discipline of middle school students are in the excellent category.

From non-numeric data, obtained in the form of suggestions / input from media experts. Suggestions / input is about the theme of the image on the cover of the guide adjusted to the title or the theme "self". In addition, media experts also suggest adding the results of the assessment to the observation sheet. Various inputs from the guidance and counseling media expert test were used as a basis for reviewing guidelines for self-teaching techniques.

The self-instruction technique guide consists of 1) Introduction; 2) General Guidelines for Self-Instruction Techniques to Increase Self-Discipline of High School Students; 3) Special Instructions for Self-Instruction Techniques to Increase Self-Discipline of High School Students; 4) Conclusions and Suggestions. The sections contained in this guide have been adapted to the needs of the contents of the guide. In the introductory chapter, it contains an introduction to guidance and counseling teachers as users of general guidelines and procedures or the stages of the implementation of self-instruction techniques implemented in this guidebook. In the general guide section, it discusses the purpose of developing the guide, the target users of the guide, and the participants of the guide. In addition, the general guidelines section also discusses the self-instruction technical activities that will be carried out in the guidebook. The next chapter is a specific guide, which in this chapter will explain in detail each procedure or stage that is designed in each meeting. There are five meetings in this handbook and in each meeting the objectives, media, time and activities are explained. In the activity points are divided into three parts, namely opening, activities, and closing. In each part of the activity the guidance and counseling teacher's task is explained in implementing the self-instruction technique.

After testing the material and media experts, a revision of the advice given by the expert on non-numeric or qualitative data is carried out. All of these suggestions have been revised by researchers to further refine this development product. 
The next step is to test prospective product users. Prospective product users in this study are guidance and counseling teachers and high school students. Numerical data from the results of test instruments for prospective guidance and counseling teacher product users that include aspects of accuracy, conformity, and clarity show a percentage of $77 \%$, which means that the self-instruction technique for improving high school student self-discipline is in an excellent category. This figure is obtained from an average of two guidance and counseling teachers as prospective users of product I and prospective users of product II.

Numerical data were also obtained from prospective product test users in high school students in small group tests. Students who were the subject were eighth grade students of Public Senior High School 1 Srengat, totaling eight people based on the results of the pretest using a self-discipline scale. After that students get treatment in the form of self-instruction techniques to improve self-discipline through a media guide of five meetings. After getting treatment, the subjects did a posttest to find out changes in the level of self-discipline. From the paired sample test the value of sig is obtained. (2 tailed) of $0.004<0.05$, which means that there is a significant difference in the level of student self-discipline that is significant between before and after treatment. The average of eight students who have a level of self-discipline in the low category turns into the high category. This shows that the selfinstruction technique guide can improve the self-discipline of high school students.

Non-numeric data comes from suggestions / input for prospective product users and prospective product users II. The advice given by prospective product users to guidance and counseling teachers is about expanding the target of research subjects that should be added to junior high school students given the students' self-discipline at that level which is not yet stable. These suggestions will be used as researchers as a reference for carrying out further research. Another suggestion is to include a research concept map. The research concept map has been designed in the research proposal so that the handbook is technical or applicative, but the input is still considered by sharpening the introduction so that the background of the guide is made clear. After testing the prospective user of the product on the guidance and counseling teacher, the next step is testing the prospective user of the product on the student or small group test. User test results on students showed significant results, where there is a difference between pretest and posttest student self-discipline through self-discipline scale after following treatment given using the self-instruction technique guide.

Self-instruction technique is a technique that is not only implemented as a description but also aims to teach a skill to the individual. This makes the self-instruction technique is ideal for application in the form of guidelines. According to Miltenberger [8], by following the self-instruction procedure, individuals are taught how to give self-instructions at the right time and in accordance with self-instructions. Media Guide makes existing procedures in self-instruction techniques more operational to be applied to school settings.
In addition, the self-instruction technique presented in the form of a guide besides being more interesting will also facilitate the user in this case the guidance and counseling teacher. According to Setyaputri [9], guidance and counseling media have functions in accordance with the objectives of the researcher including 1) Clarifying guidance and counseling messages so that they are not too verbalistic; 2) Gives students interest, more direct interactions between students and guidance and counseling's teachers; 3) Increase the interactivity of the guidance and counseling's service process; 4) Improve the quality of guidance and counseling's services; 5) Increase students' positive attitude towards guidance and counseling's service material; 6) Increase creativity both in terms of the guidance and counseling's Teacher and students.

The self-instruction technique guide clarifies the message that will be delivered to the user which is not enough if only verbal. The stages of the self-instruction technique in the guide are simplified in counseling meetings, each of which has a description of goals, time, and activities. This can make it easier for guidance and counseling teachers to increase student interest in participating in counseling activities. Besides having a description of the objectives, time, and activities in each meeting, in the self-instruction technique guide there is also an interactive worksheet for students. The instructions on the worksheet are as communicative as possible to make it easier for students to fill out.

The technique of self-instruction emphasizes that to achieve self-awareness, the counselee involves increasing sensitivity to thoughts, feelings, and actions [10]. According to Meichenbaum [11], self-instruction techniques also encourage self-control. Self-awareness and self-control are two interrelated things to bring about self-discipline. Brooks and Goldstein [12] state that self-discipline is a major component in a person as a form of accountability for his behavior. They also revealed that having self-discipline and using it effectively would open up success in adulthood.

Self-discipline requires control and requires the ability to create conscious business, not effort that just happens [13]. Through the self-instruction technique guide, students are taught to achieve self-awareness and then are asked to explore what is being thought when dealing with self-discipline, how feelings are experienced, how they occur, and what causes them. This is not easy if only conveyed verbally, so with the help of worksheets in the guide can make it easier for students to describe their thoughts, feelings, and actions.

In the self-instruction technique, there is a stage of selfguidance taught to students. Through the self-instruction technique guide, the guidance and counseling teacher is asked to become a model to practice. Counseling teachers can follow the steps in the guide by calling out positive self-talk in a loud and loud voice, which is then followed by the counselee in a loud voice then whispering and in the heart. The activity is then followed by students by previously filling out a selfguidance worksheet to be more structured and easily understood. 


\section{CONCLUSION}

Based on the results of the study it can be concluded that the self-instruction technique guide to improve the selfdiscipline of high school students developed can be accepted theoretically and practically as a type of guidance and counseling media. This can be seen from the assessment of expert tests and testing of prospective product users, namely guidance and counseling teachers and students who show very good categories, and prospective product user tests show good categories. In the prospective product user test on students or small group test also shows that the self-instruction technique guide can improve student self-discipline with significant results.

\section{REFERENCES}

[1] L. Arofah, "Pentingnya siswa memiliki self discipline sebagai alternatif penguatan karakter," 2017.

[2] T. Bryant, Self discipline in 10 days: how to go from thinking to doing. 2011.

[3] T. Susana, E. H. Parmadi, and P. S. Adi, "Program Bantu Diri Terapi Kognitif Perilaku: Harapan bagi Penderita Depresi,” J. Psikol., 2015.

[4] J. Clore and S. Gaynor, "Self-statement modification techniques for distressed college students with low self-esteem and depressive symptoms.," Int. J. Behav. Consult. Ther., 2006.

[5] G. Corey, Theory and practice of counseling and psychotherapy. 2009.

[6] W. R. Gall, M. D., Gall, J. P., \& Borg, Educational research: An introduction (7th ed.). 2003.

[7] N. Sudjana, Penilaian Hasil Proses Belajar Mengajar. 2011.

[8] R. G. Miltenberger, Behavior Modification: Principles and Procedures 5th Edition. 2012.

[9] N.Y. Setyaputri, "Urgensi pemanfaatan media bimbingan dan konseling dalam proses layanan bimbingan dan konseling," 2018.

[10] R. D. Nawantara, "Perbedaan Komitmen Tugas Siswa dalam Penerapan Teknik Reframing dan Self Instruction," J. Pendidik. Hum., vol. 4, no. 4, pp. 193-199, 2016.

[11] D. Meichenbaum, "Cognitive Behaviour Modification," J. Scand. J. Behav. Ther., vol. 6, no. 4, pp. 185-192, 1977.

[12] S. Brooks, R. \& Goldstein, Raising A Self Disciplined Child. 2009.

[13] S. N. Mbaluka, "The impact of student self-discipline and parental involvement in students' academic activities on student academic performance.," Diss. Abstr. Int. Sect. A Humanit. Soc. Sci., 2018. 